\title{
Kondisi Optimum untuk Produksi Kitinase dari Streptomyces Rkt5 dan Karakterisasi pH dan Suhu Enzim
}

\section{Optimum Condition for Chitinase Production from Streptomyces Rkt5 and Characterization of pH and Temperature of Enzyme}

\author{
Yurnaliza $^{1 *}$, Sebastian Margino ${ }^{2}$, Langkah Sembiring ${ }^{3}$ \\ ${ }^{1}$ Departemen Biologi FMIPA Universitas Sumatera Utara, Jalan Bioteknologi No.1 Medan, 20155 \\ E-mail: yurnaliza@usu.ac.id *Penulis untuk korespondensi \\ ${ }^{2}$ Fakultas Pertanian Universitas Gadjah Mada, Bulaksumur Yogyakarta 55281 \\ ${ }^{3}$ Fakultas Biologi Universitas Gadjah Mada Jl. Teknika Selatan, Yogyakarta 55281
}

\begin{abstract}
Chitinase is chitin degrading enzyme which is produced by Streptomyces Rkt $\mathbf{5}$ is isolated microorganism from peanut rhizosfer. This enzyme and its microorganism can be used in many agricultural, medicine and industrial purposes. The aim of the research was to find out the optimum condition for production of chitinase and to characterize of $\mathrm{pH}$ and temperature to chitinase activity. Optimalizing production the research had 4 treatments. The optimum conditions were achieved at mineral liquid medium containing with chitin $0,2 \%(w / v)$ as inducer, $10 \%(v / v)$ inoculum, $\mathrm{pH} 7$ and 48 hours incubation. The crude enzyme was partially purified by salting out with $70 \%$ ammonium sulfate resulted in 3.31 time more purity enzyme than the crude one. This enzyme had maximum activity at $50^{\circ} \mathrm{C}$ and $\mathrm{pH} 5.5$.
\end{abstract}

Key words: chitinase, optimum condition, Streptomyces Rkt5, enzyme activity

Diterima: 01 Oktober 2007, disetujui: 29 September 2008

\section{Pendahuluan}

Kitinase adalah enzim yang mampu menghidrolisis kitin (polimer dari $\beta-1,4 \mathrm{~N}-$ setil-D-glukosamin) yang merupakan suatu polisakarida kedua terbanyak di alam setelah selulosa. Enzim ini dihasilkan oleh beberapa jenis mikroorganisme, tumbuhan dan hewan. Enzim kitinolitik umumnya diinduksi dalam bentuk kompleks enzim dan berdasarkan cara kerjanya dibagi atas tiga tipe yaitu endokitinase (EC. 3.2.1.14), eksokitinase dan $\beta-1,4-\mathrm{N}-$ asetilglukosamidase (EC. 3.2.1.30) (Sahai dan Manocha, 1993). Berdasarkan urutan asam aminonya kitinase dibagi atas tiga famili yaitu famili 18, 19 dan 20. Famili 18 meliputi kitinase dari bakteri, jamur, serangga, tanaman (kelas III dan V) dan hewan. Famili 19 diidentifikasi dari tanaman (kelas I, II, dan IV) dan bakteri gram positif Streptomyces.
Sedangkan famili 20 dari Vibrio harveyi (Watanabe et al., 1999; Patil et al., 2000).

Kitinase di alam memberikan kontribusi yang berarti bagi penelitian ilmu dasar dan terapan. Penelitian mengenai peran enzim kitinase banyak dilakukan dalam berbagai bidang. Di laboratorium kitinase digunakan untuk mengisolasi protoplas dari jamur dan khamir. Hasil hidrolisis kitin berupa senyawa kitooligosakarida bermanfaat dalam dunia kesehatan karena memiliki aktivitas anti tumor. Dalam bidang pertanian, kitinase dan mikroorganisme penghasilnya berperan sebagai agen pengendali hayati penyakit tanaman yang disebabkan oleh jamur. Kitinase menyebabkan terjadinya lisis pada dinding sel jamur yang umumnya mengandung kitin (Shaikh dan Deshpande, 1993; El-Katatny et al., 2000; Patil et al., 2000; Gohel et al., 2006). 


\begin{abstract}
Diantara mikroorganisme penghasil kitinase yang banyak mendapat perhatian diantaranya adalah genus Streptomyces. Sebanyak $25 \%$ dari dari anggota genus ini adalah pendegradasi kitin yang baik, bahkan media kitin agar adalah media pertumbuhan yang digunakan untuk mengisolasi genus ini (Labeda dan Shearer, 1990).
\end{abstract}

Eksplorasi kemampuan kitinolitik Streptomyces banyak dilakukan untuk mempelajari mekanisme sintesis kitinase secara ekstraseluler. Streptomyces Rkt5 adalah bakteri kitinolitik yang telah diketahui memiliki kemampuan kitinolitik yang tinggi (Yurnaliza et al., 2003). Kemampuan sekresi kitinase dari mikroorganisme khusunya Streptomyces dipengaruhi oleh berbagai kondisi lingkungan. Kondisi lingkungan yang optimum sangat diperlukan untuk mendapatkan enzim kitinase dengan kemampuan kitinolitik yang tinggi.

Pada penelitian ini berberapa kondisi pertumbuhan seperti konsentrasi substrat, konsentrasi inokulum, $\mathrm{pH}$ dan waktu inkubasi divariasikan untuk mendapatkan kondisi optimum dalam produksi enzim serta karakterisasi suhu dan $\mathrm{pH}$ terhadap aktivitas kitinase.

\section{Metode Penelitian}

\section{Organisme dan kondisi pertumbuhan}

Bakteri penghasil kitinase yang digunakan Streptomyces Rkt 5 isolat rizosfer kacang tanah (Yurnaliza et al., 2003). Produksi enzim dilakukan pada skala erlenmeyer dengan kondisi pertumbuhan meliputi beberapa variasi konsentrasi inokulum yaitu 5, 10, 15, 20\% (v/v); pH medium 5, 6, 7 dan 8, konsentrasi kitin sebanyak 0,$2 ; 0,5$ dan $1 \%(\mathrm{~b} / \mathrm{v})$ dan waktu inkubasi secara periodik setiap 12 jam. Optimalisasi dilakukan bertahap. Hasil terbaik dari masing-masing tahap dijadikan acuan untuk perlakuan berikutnya. Kondisi awal optimalisasi adalah konsentrasi inokulum 5\% (v/v); pH 6,8; konsentrasi kitin 0,2\% (b/v) dan waktu inkubasi 72 jam.

Medium kultivasi yang digunakan adalah Medium Mineral Kitin Cair yang setiap liternya mengandung $0,7 \mathrm{~g} \mathrm{~K}_{2} \mathrm{HPO}_{4} ; 0,3 \mathrm{~g} \mathrm{KH}_{2} \mathrm{PO}_{4} ; 0,5$ $\mathrm{g} \mathrm{MgSO}_{4} \cdot 7 \mathrm{H}_{2} \mathrm{O} ; 0,01 \mathrm{~g} \mathrm{FeSO} 4 \cdot 7 \mathrm{H}_{2} \mathrm{O} ; 0,001 \mathrm{~g}$
$\mathrm{ZnSO}_{4} ; 0,001 \mathrm{~g} \mathrm{MnCl}_{2}$ dan 0,2\% koloidal kitin (Hsu dan Lockwood, 1975). Koloidal kitin dipreparasi secara hidrolisis parsial menggunakan $\mathrm{HCl} 10 \mathrm{~N}$ (Labeda dan Shearer, 1990).

Enzim dipanen dengan cara sentrifugasi medium kultivasi pada $4000 \mathrm{rpm}$ selama 20 menit pada suhu $4^{\circ} \mathrm{C}$. Supernatan yang diperoleh merupakan enzim kasar dan untuk pengujian lebih lanjut dapat disimpan pada suhu $0^{\circ} \mathrm{C}$. Berat kering sel ditentukan dengan sentrifugasi $10 \mathrm{ml}$ medium kultivasi pada 4000 rpm selama 20 menit. Pelet yang terbentuk dikeringkan dengan oven pada suhu $80^{\circ} \mathrm{C}$ kemudian ditimbang sampai diperoleh berat konstan.

\section{Pengukuran aktivitas enzim}

Enzim kasar dan substrat kitin $[1 \%$ koloidal kitin (b/v) dalam $50 \mathrm{mM}$ buffer fosfat, $\mathrm{pH} 6,8]$ dicampur dengan volume yang sama dan diinkubasi pada suhu $37^{\circ} \mathrm{C}$ selama 60 menit. Reaksi dihentikan dengan memanaskan campuran dalam air mendidih selama 15 menit dan kemudian disentrifugasi pada $3000 \mathrm{rpm}$ selama 20 menit. $\mathrm{N}$-asetilglukosamin (NAG) yang dihasilkan dianalisis secara kolorimetri dengan metode Reissig (1955) (Muzarelli dan Peter, 1997). Satu unit aktivitas enzim kitinase didefinisikan sebagai jumlah enzim yang membebaskan sebanyak $1 \mu \mathrm{mol} \mathrm{GlcNac/jam.}$ Sedangkan aktivitas spesifik kitinase adalah 1 $\mathrm{U} / \mathrm{mg}$ protein. Penentuan jumlah protein terlarut ditentukan dengan metode Lowry (Plummer, 1978).

\section{Produksi kitinase dan purifikasi parsial}

Kitinase kasar yang dihasilkan Streptomyces Rkt5 dalam kondisi optimum, dipanen dan dipekatkan secara freeze drying. Selanjutkan dipresipitasi dengan ammonium sulfat $70 \%$ selama 1 malam pada suhu $4^{\circ} \mathrm{C}$. Presipitat didialisis dengan membran dialisis (MWCO 12.000, Sigma) dalam cairan $50 \mathrm{mM}$ buffer fosfat $\mathrm{pH}$ 6,8. Dialisat yang diperoleh dikarakterisasi aktivitas maksimumnya pada $\mathrm{pH}$ dan suhu yang berbeda. 


\section{Karakterisasi pH dan suhu untuk aktivitas enzim}

Variasi $\mathrm{pH}$ yang digunakan yaitu 3 sampai 8 dengan interval 0,5 . Buffer yang digunakan untuk pH $3-5,5$ adalah $50 \mathrm{mM}$ buffer sitrat dan untuk pH $6-8$ digunakan 50 $\mathrm{mM}$ buffer fosfat. Variasi suhu adalah antara $30-70^{\circ} \mathrm{C}$ dengan interval $5^{\circ} \mathrm{C}$ dengan kondisi $\mathrm{pH}$ optimum.

\section{Hasil dan Pembahasan}

Optimalisasi kondisi medium fermentasi pada penggunaan variasi konsentrasi inokulum, $\mathrm{pH}$, konsentrasi substrat dan waktu inkubasi mempengaruhi produksi kitinase dan pertumbuhan sel Streptomyces Rkt5. Kitinase yang dihasilkan menunjukkan aktivitas spesifik tertinggi pada penggunaan inokulum $10 \%$ yaitu sebesar 0,482 U/mg, dan aktivitas menurun pada konsentrasi 15 dan 20\% (Gambar 1a). Konsentrasi inokulum di atas $10 \%$ tidak mempengaruhi pertumbuhan sel. Jumlah inokulum yang melebihi jumlah optimum tidak menyebabkan peningkatan aktivitas enzim. Penggunaan inokulum yang tepat dapat mempercepat proses fermentasi dengan mengurangi lamanya fase lag (Stanbury dan Whitaker, 1984).

Produksi kitinase oleh Streptomyces RKt5 dihasilkan tertinggi pada medium dengan pH 7 dengan aktivitas spesifik enzim sebesar $0,555 \mathrm{U} / \mathrm{mg}$. Peningkatan produksi kitinase dimulai pada $\mathrm{pH} 6$ dan menurun pada $\mathrm{pH} 8$. Kondisi optimum $\mathrm{pH}$ untuk produksi kitinase Streptomyces RKt-5 berada pada kisaran $\mathrm{pH}$ antara 6-8 (Gambar 1b). Beberapa penelitian enzim menunjukkan bahwa $\mathrm{pH}$ yang berada pada kisaran netral meningkatkan pertumbuhan Aktinomiset dan kemampuannya mensintesis enzim kitinase. Kitinase dari Streptomyces sp. 385 dan Streptomyces halstedii AJ-7 juga diproduksi pada kisaran $\mathrm{pH}$ netral yaitu $\mathrm{pH} 6,8$ dan 7 (Singh et al., 1999 dan Joo, 2005). Streptomyces RKt5 pada pH 7 dan 8 memiliki biomasa sel terbanyak yaitu dengan berat kering selnya sebanyak $1,79 \mathrm{mg} / \mathrm{ml}$. Crawford et al., (1993) menyatakan bahwa Aktinomisetes tumbuh baik pada $\mathrm{pH} 6,8-8$ walaupun ada yang mampu tumbuh pada $\mathrm{pH}$ 5,5 - 6 .
Perbedaan konsentrasi kitin berpengaruh terhadap produksi kitinase dan biomassa sel Streptomyces RKt5. Kitinase yang dihasilkan memilki aktivitas spesifik tertinggi yaitu sebesar $0,555 \mathrm{U} / \mathrm{mg}$ pada medium dengan kandungan kitin sebanyak $0,2 \%$, sedangkan pada konsentrasi 0,5 dan $1 \%$ aktivitas kitinase semakin menurun (Gambar 1c). Konsentrasi kitin $0,2 \%$ adalah konsentrasi optimum untuk produksi kitinase. Biomassa sel Streptomyces RKt5 meningkat dengan semakin meningkatnya konsentrasi kitin. Konsentrasi substrat yang tinggi menyebabkan arah fermentasi lebih mengarah kepada pembentukan biomasa sel daripada pembentukan produk metabolit (Stanbury dan Whitaker, 1984). Sehingga hanya diperlukan kitin sebanyak $0,2 \%$ untuk menginduksi kitinase dengan aktivitas maksimum.

Produksi kitinase memberikan aktivitas spesifik dan berat kering sel tertinggi pada waktu inkubasi 48 jam yaitu sebesar 0,443 $\mathrm{U} / \mathrm{mg}$ dan sebanyak $1,757 \mathrm{mg} / \mathrm{ml}$ (Gambar 1d). Aktivitas kitinase menurun setelah pertumbuhan sel mencapai fase stasioner. Waktu inkubasi 48 jam dipilih sebagai waktu inkubasi optimum untuk produksi enzim kitinase dari Streptomyces RKt5. Waktu inkubasi 48 jam adalah waktu inkubasi optimum untuk produksi enzim kitinase pada isolat Rkt5. Bakteri Streptomyces CU 36 dan Streptomyces CU 105 (Kamel et al., 1993) memiliki aktivitas kitinase maksimal pada kultur berumur 72 dan 84 jam.

\section{Purifikasi parsial}

Tingkat kemurnian enzim yang dihasilkan menggunakan ammonium sulfat $70 \%$ sebanyak 3,13 kali enzim kasarnya (Tabel 1). Penelitian Joo (2005) dengan prosedur yang sama mendapatkan tingkat kemurnian enzim yang lebih tinggi yaitu sebanyak 6,8 kali enzim kasar, sedangkan penelitian Singh et al., (1999) menggunakan polietilen glikol (PEG \# 6000) memperoleh tingkat kemurnian enzim sebanyak 11,9 kali enzim kasarnya.

Presipitasi protein enzim dapat juga dilakukan dengan menggunakan etanol dan aseton. Amonium sulfat, etanol, dan aseton memberikan pengaruh yang sama terhadap pengendapan protein, yaitu dengan cara 
mempengaruhi aktivitas air. Pada pemurnian enzim kitinase dari jamur Scleroderma columnare dan Trichoderma harzianum oleh Wijaya (2002) menggunakan ammonium sulfat, aseton dan alkohol sebagai presipitat diperoleh enzim murni dengan aktivitas yang lebih tinggi pada penggunaan ammonium sulfat sebagai presipitat dibandingkan dengan aseton dan alkohol. Penggunaan Amonium sulfat memberikan beberapa keuntungan, antara lain dapat digunakan pada $\mathrm{pH}$ tinggi $(\mathrm{pH}>10)$, kelarutan dalam air tinggi (533 g/L pada suhu $20^{\circ} \mathrm{C}$ ), dan tidak beracun. Ammonium sulfat dengan konsentrasi tinggi menyebabkan muatan listrik di sekitar molekul protein meningkat dan menarik mantel air yang ada di sekeliling molekul protein, sehingga kelarutan protein menurun (Scopes, 1994).
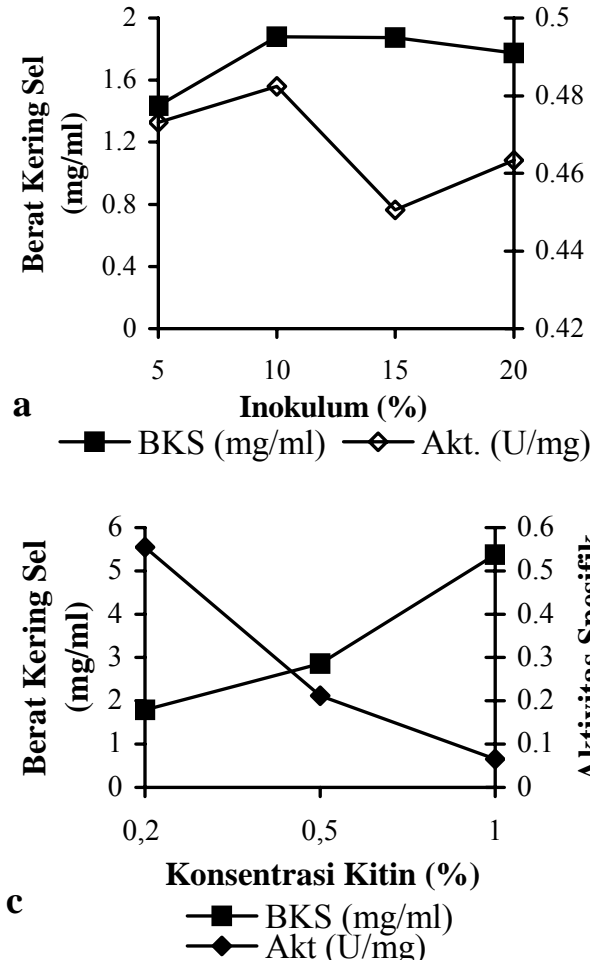
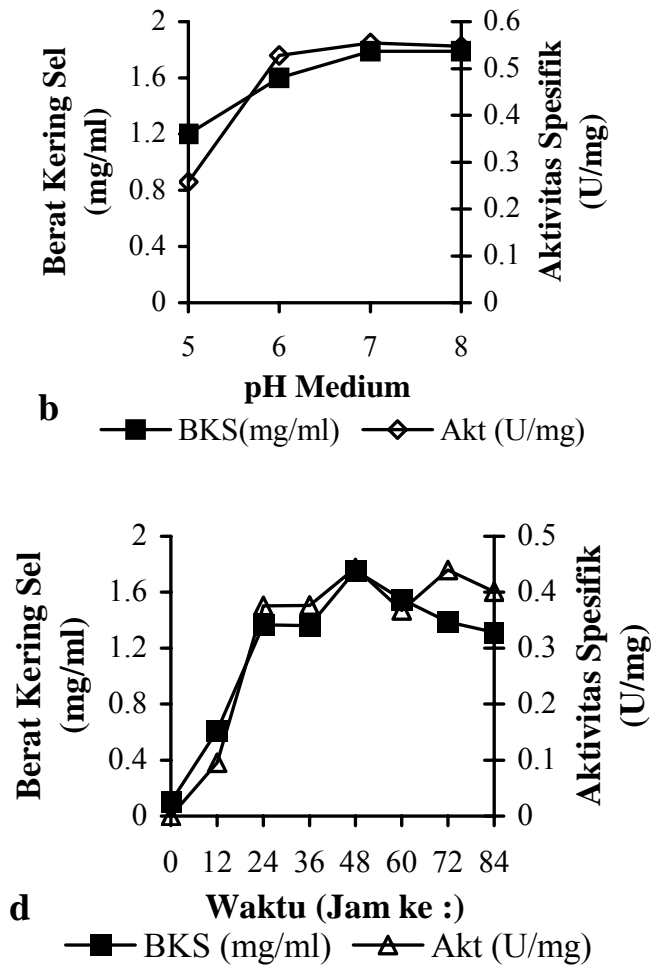

Gambar 1. Produksi kitinase terhadap perbedaan konsentrasi inokulum (a), $\mathrm{pH}$ (b), konsentrasi kitin (c) dan waktu inkubasi (d), Akt (Aktivitas spesifik) enzim, BKS (berat kering sel).

Tabel 1. Rekapitulasi pemurnian enzim kitinase sampai tahap dialisis.

\begin{tabular}{|c|c|c|c|c|c|c|}
\hline $\begin{array}{c}\text { Kejenuhan } \\
\left(\mathrm{NH}_{4}\right)_{2} \mathrm{SO}_{4}(\%)\end{array}$ & $\begin{array}{l}\text { Vol. } \\
\text { (ml) }\end{array}$ & $\begin{array}{l}\text { Total Protein } \\
\text { (mg) }\end{array}$ & $\begin{array}{c}\text { Total } \\
\text { aktivitas (U) }\end{array}$ & $\begin{array}{l}\text { Akt.spe. }^{\text {a) }} \\
\left.\text { (U. mg }{ }^{-1}\right)\end{array}$ & $\begin{array}{c}\text { Tingkat } \\
\text { Kemurnian }\end{array}$ & $\begin{array}{l}\text { Yield } \\
(\%)\end{array}$ \\
\hline Enzim kasar & 5000 & 493,0 & 337,0 & 0,68 & 1 & 100 \\
\hline Hasil dialisis ${ }^{\text {b) }}$ & 8 & 71,36 & 152,20 & 2,13 & 3,13 & 45,16 \\
\hline
\end{tabular}

Keterangan:

a) Aktivitas enzim diuji dengan substrat kitin koloid 1\% (b/v), waktu inkubasi 60 menit suhu $37^{\circ} \mathrm{C}$, dan $\mathrm{pH} 6,8$.

b) Hasil dialisis berasal dari presipitasi protein dengan ammonium sulfat pada tingkat kejenuhan $70 \%$ (b/v). 


\section{Aktivitas kitinase terhadap variasi $\mathbf{p H}$ dan suhu}

Aktivitas enzim kitinase tertinggi dicapai pada $\mathrm{pH}$ 5,5 (Gambar 2) dan menurun secara perlahan pada $\mathrm{pH}$ di bawah dan di atas 5,5. Kisaran $\mathrm{pH}$ untuk aktivitas kitinase berada antara $\mathrm{pH} 5-6,5$. Hal ini sesuai dengan yang dinyatakan oleh Tsujibo et al., (1992) bahwa aktivitas kitinase Aktinomisetes dan jamur berada pada suasana asam. Kitinase yang dihasilkan oleh Streptomyces sp. M-20 (Kim, et al., 2003) aktif pada $\mathrm{pH}$ 5. Kitinase Streptomyces RKt-5 pada $\mathrm{pH} 3$ dan 3,5 memperlihatkan aktivitas dengan nilai yang sangat rendah yaitu 4,509 $\mathrm{U}$ dan 8,568 $\mathrm{U}$.
Suhu optimum kitinase dicapai pada $50^{\circ} \mathrm{C}$ dengan aktivitas sebesar 42,312 U (Gambar 2). Aktivitas kitinase semakin meningkat seiring dengan meningkatnya suhu. Kisaran suhu untuk aktivitas kitinase cukup luas yaitu antara $35-60^{\circ} \mathrm{C}$ dengan suhu optimum $50^{\circ} \mathrm{C}$. Aktivitas kitinase dari Streptomyces Rkt5 optimum pada suhu tinggi, tapi tidak dapat dipastikan apakah enzim ini stabil pada suhu tersebut. Bakteri S. halstedii AJ-7 dilaporkan juga memiliki aktivitas kitinase pada suhu $50^{\circ} \mathrm{C}$ (Joo, 2005), tetapi hasil penelitan Kim, et al., (2003) mendapatkan enzim kitinase dengan suhu optimum $30^{\circ} \mathrm{C}$ dan hanya stabil sampai suhu $40^{\circ} \mathrm{C}$.

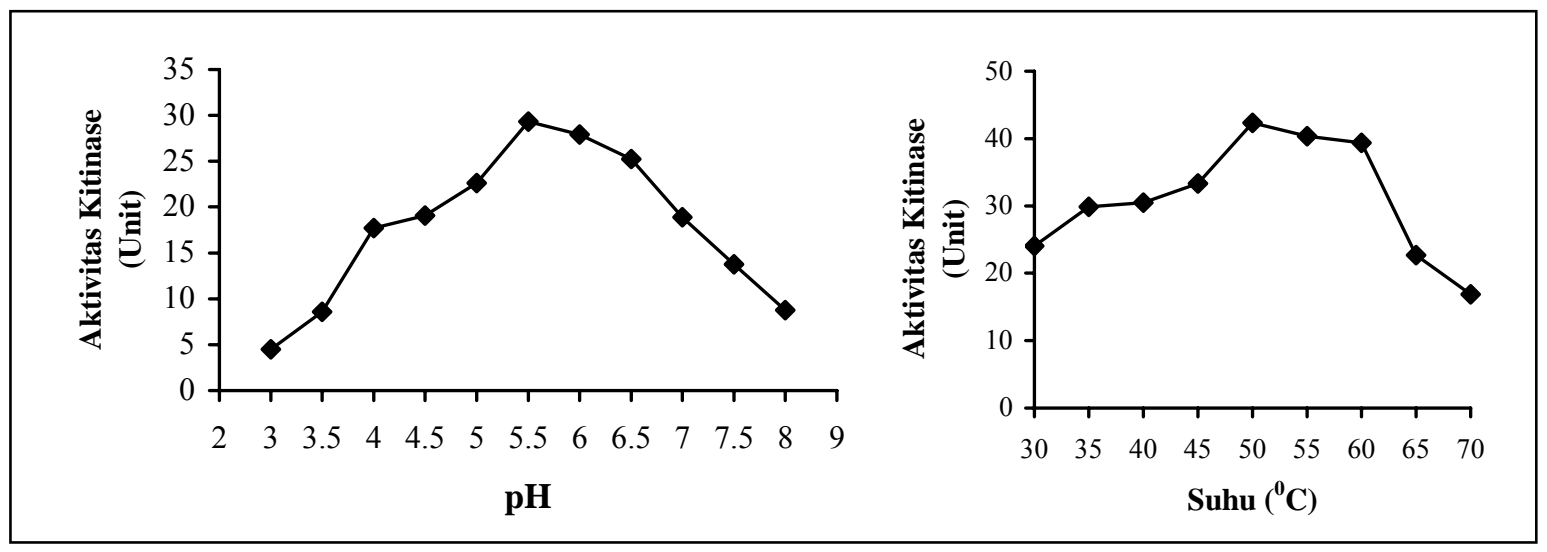

Gambar 2. Aktivitas kitinase Streptomyces Rkt5 pada beberapa variasi $\mathrm{pH}$ dan suhu.

\section{Kesimpulan}

Enzim kitinase adalah enzim ekstraseluler yang dalam proses produksinya dipengaruhi faktor-faktor lingkungan seperti konsentrasi substrat, inokulum $\mathrm{pH}$ lingkungan, suhu waktu inkubasi dan lain sebagainya. Pada produksi enzim kitinase dari Streptomyces Rkt5 didapatkan kondisi optimum media fermentasi dengan kandungan kitin koloid $0,2 \%$, dengan inokulum $10 \%, \mathrm{pH} 7$ dan waktu inkubasi 48 jam. Pada kondisi ini didapatkan enzim dengan aktivitas spesifik tertinggi. Purifikasi parsial enzim kitinase kasar dari Streptomyces Rkt5 dengan ammonium sulfat $70 \%$ dihasilkan enzim dengan kemurnian yang meningkat sebanyak 3,31 kali. Enzim kitinase ini memiliki karakteristik $\mathrm{pH}$ sedikit asam dengan kisaran
$\mathrm{pH} 5-6,5$ dengan aktivitas tertinggi pada $\mathrm{pH}$ 5,5. Sementara karakter suhu enzim kitinase dari Streptomyces Rkt5 ini berada pada suhu optimum $50^{\circ} \mathrm{C}$ dengan kisaran suhu antara $35-$ $60^{\circ} \mathrm{C}$.

\section{Ucapan Terima Kasih}

Ucapan terima kasih disampaikan kepada Kepala Lab. Mikrobiologi Tanah, Fakultas Pertanian Universitas Gadjah Mada Yogyakarta yang telah memberikan fasilitas dalam melakukan penelitian ini. Terima kasih juga kepada Saifur Rahman S.P, M.Si yang telah memberikan masukan dan saran selama melakukan penelitian. 


\section{Daftar Pustaka}

Crawford, D.L., Lynch., J.M., Whipps, J.M. and Ousley, M.A. 1993. Isolation and Characterization of Actinomycete Antagonist of A Fungal Root Pathogens. Appl. Environ. Microbiol. 59: 3899-3905.

El-Katatny, M.H., Somitsch, W., Robra, K.H., El-Katatny, M.S. and Gübitz, G.M. 2000. Production of Chitinase and $\beta$-1,3-glucanase by Trichoderma harzianum for Control of the Phytopathogenic Fungus Sclerotium rolfsii. Food technol. biotechnol. 38 (3): 173-180.

Gohel, V., Singh, A., Vimal, M., Ashwini, P. and Chhatpar, H.S. 2006. Review. Bioprospecting and Antifungal Potential Chitinolytic Microorganisms. African J. of Biotechnology 5 (2): $54-72$.

Hsu, S.C. and Lockwood, J.L. 1975. Powdered Chitin Agar as a Selective Medium for Enumeration of Actinomycetes in Water and Soil. Appl. Microbiol. 29: 422-426.

Joo, G.J. 2005. Purification and Characterization of an Extracellular Chitinase from the Antifungal Biocontrol Agent Streptomyces halstedii. Biotechnology Letters 27: 1483-1486.

Kamel, Z., Heikel, N. and Fahmy, F. 1993. Extracellular Chitinase from Streptomyces Species and Its Antifungal Activity. Acta Pharmaceutica Turcica. 35: 135-143.

Kim, K.J., Yang, Y.J. and Kim, J.G. 2003. Purification and Characterization of Chitinase from Streptomyces sp. M-20. J. Biochem. Mol. Biol.36 (2): 185-189.

Labeda, D.P. and Shearer, M.C. 1990. Isolation of Actinomycetes for Biotechnological Applications. In: D.P. Labeda (Eds.) Isolation of Biotecnological Organisms from Nature: 119. McGraw-Hill Publishing Campany.

Muzzarelli R.A.A 1997. The Determination of Minute Quantities of Chitin in Tissues. In: Muzarelli, R.A.A. and Peter, M.G. (Eds). Chitin Handbook. European Chitin Society. hlm 1525
Patil, R.S., Ghormade, V. and Despande, M.V. 2000. Chitinolytic Enzymes: an Exploration. Enzyme and Microbial Technology 26: 473483.

Plummer, D.T. 1978. An Introduction to Practical Biochemistry. $2^{\text {nd }}$ Ed. Tata Mc Graw-Hill Publishing Company Ltd., New Dehli.

Sahai, A.S. and Manocha, M.S. 1993. Chitinases of Fungi and Plants: Their Involvement in Morphogenesis and Host-Parasite Interaction. FEMS Microbiol. Rev. 11: 317-338.

Scopes, R.K. 1994. Protein Purification, Principles and Practice. Third Edition. Springer, New York.

Shaikh, S.A. and Deshpande, M.V. 1993. Review. Chitinolytic Enzymes: Their Contribution to Basic and Applied Research. World J. Microbiol. Biotech, 9: 468-475.

Singh, P.P., Shin, Y.C., Park, C.S. and Chung, Y.R. 1999. Biological Control of Fusarium Wilt of Cucumber by Chitinolytic Bacteria. Phytopathology. 89: 92-99.

Stanbury, P.F. and Whitaker, A. 1984. Principles of Fermentation Technology. Pergamon Press, Oxford.

Tsujibo, H., Yoshida, Y., Miyamoto, K., Hasegawa, T. and Inammori, Y. 1992. Purification and Properties of Two Types of Chitinases Produced by an Alkalophilic Actinomycete. Biosci. Biotechnol. Biochem. 56: 1304-1305.

Watanabe, T, Kanai, R., Kawase, T., Tanabe, T., Mitsutomi, M., Sakuda, M. and Miyashita, K. 1999. Family 19 Chitinases pof Streptomyces species: Characterization and Distribution. Microbiol. 145: 3353-3363.

Wijaya, S.K.S. 2002. Isolasi Kitinase dari Scleroderma columnare dan Trichoderma harzianum (Isolation of Chitinase From Scleroderma columnare and Trichoderma harzianum). J. Ilmu Dasar 3 (1): 30-35.

Yurnaliza, Margino, S. dan Sembiring, L. 2003. Isolasi Aktinomisetes Kitinolitik Dari Rhizosfer dan Kompos. Komunikasi Penelitian 15 (2): 2735 . 